\title{
The Hierarchy of Remedies Under the WTO Dispute Settlement System and Its Impact
}

\author{
Wei Zhang \\ Guanghua Law School \\ Zhejiang University \\ Hangzhou, China
}

\begin{abstract}
The dispute settlement system of the World Trade Organization (WTO) has been treated as the most effective mechanism in terms of international rule of law since it was born. The objective of the dispute settlement system is providing the multilateral trading system with security and predictability. There are three types of remedy under the WTO Understanding on Rules and Procedures Governing the Settlement of Disputes (commonly known as the DSU) that designed for breach of WTO law. ${ }^{1}$ The first one is withdrawal of the measures that are inconsistent with the WTO covered agreements, which is a final remedy. Another two remedies are temporary remedies, the compensation and suspension of concessions or other obligations ${ }^{2}$ under the covered agreements. This is the compliance-compensation-retaliation remedy system under the DSU of the WTO. ${ }^{3}$ Among these remedies, effectiveness can be seen. However, these remedies also have their own shortage, especially when the developing countries using them. The purpose of the essay is through showing the remedies under the DSU to demonstrate both the significance and deficiency of this remedy system, especially its impacts on the developed and developing countries.
\end{abstract}

Keywords-WTO; DSU; remedies; impact

\section{INTRODUCTION}

Article 3.7 of the DSU states, "A solution mutually acceptable to the parties [...] is clearly to be preferred". That is to say the DSU in favor of parties settle dispute out of court because it is cheaper and effectiveness through consultation to settle the dispute than the panel. ${ }^{4}$ If this does not happen, just as the records that "in the absence of a mutually agreed solution, the first objective of the dispute settlement mechanism is usually to secure the withdrawal of the measures concerned if these are found to be inconsistent with the provisions of any of the covered agreements" 5 . And a 'reasonable period of time' is given to the defending Member State to bring its policy into conformity with the

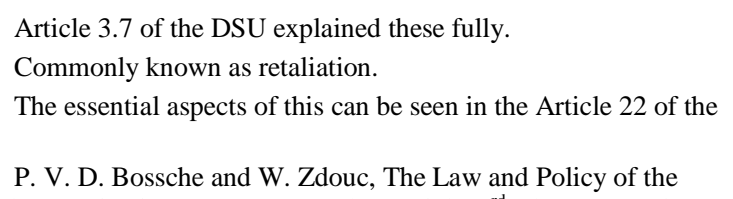

WTO rules. ${ }^{6}$ If the defending Member State is regardless of the rules and reluctant to change the inconsistent policy, in order to find reciprocally acceptable compensation, a consultation should begin before that time period expires between the complaining and defending Member States., If all other methods under the WTO dispute settlement mechanism is uselessness, the complaining Member State would impose trade sanctions on the defending Member State which measures are violate the WTO obligations. ${ }^{7}$ That is within 20 days after expiry of the 'reasonable period of time', there is still no satisfactory agreement reached between them, and then the complaining Member can ask the WTO's Dispute Settlement Body (DSB) for authorization to 'suspend concessions or other obligations, ${ }^{8}$. However, the retaliatory measures cannot exceed the level of nullification or impairment.

\section{DETAILS OF THE HIERARCHY OF REMEDIES UNDER THE WTO}

\section{A. Withdrawal of Inconsistent Measures}

The most common remedy under the WTO dispute settlement system is the withdrawal of inconsistent measures. The reasonable period of time to implement Panel or Appellate Body reports should not exceed 15 months from the date of the adaption of a Panel or Appellate Body report. ${ }^{9}$ In other words, it is a recommendation of conformity and it is easy for a case to be solved both for developed and developing countries. In United States-Taxes on Conventional and Reformulated Gasoline ${ }^{10}$, the United States violated the 'no less favorable treatment' rule and carried on a consistent measure at the end of the reasonable period time, so the case was solved. In many cases the panels just made a ruling or reached other conclusions. In this way, the adjudicating bodies give sufficient discretion to the

\footnotetext{
Article 21.3 of the DSU.

A. Guzman and B. A. Simmons, "To settle or empanel? an empirical analysis of litigation and settlement at the world trade organization," vol. 31, Journal of Legal Studies, 2002, pp. 207-208.

According to Article 3.7 of the DSU, this action is treated as the 'last resort' in dealing with the dispute.

9 Article 21.3(c) of the DSU.

10 More details see

https://www.wto.org/english/tratop_e/dispu_e/cases_e/ds2_e.htm.
} 
defending Member State to decide the appropriate remedy. ${ }^{11}$ In principle, the WTO Members are free to choose any manners that they think appropriate in order to bring their measures in conformity with the WTO obligations. Thus, after up to 15 months the defending Member State may fulfill its obligation to change its measure totally. However, the point is here, whether there is still a disagreement between the Members in terms of the adequacy of the implementing measure. If the complaint state thinks it is inadequacy, the only thing it can do is request a panel ${ }^{12}$ to pronounce, and it cannot adopt countermeasures at all, because it is not the same dispute. This circumstance is fully demonstrated in the Bananas case. In this case, the Appellate Body requested the EC to bring its measures in comply with its obligations. However, the EC just made some changes and the United States thought it was inadequacy and still violated the obligations. After that, a panel was established to deal with this issue. At the moment, the dispute Members could no longer reach an agreement on the interpretation of DSU. Furthermore, the United States even retaliated in advance, before the panel's pronounce. This phenomenon illustrates that the existing system cannot cope with this kind of issue effectively. ${ }^{13}$ This circumstance may equally happen to all WTO Member States.

\section{B. The Compensation}

Usually the compensation is trade compensation, through tariff reductions or import quotas addition by the defending Member State compensates to the complaining Member State. ${ }^{14}$ Traditionally, the compensation is treated as an adjustment of trade concessions by the defending Member State to make up its wrong action. However, since the USSection 110(5) of the US Copyright Act, the opinion to compensation has been changed to obstruct to the use of further payment option and to harm to the poor countries. ${ }^{15}$ At the same time, it is difficult to calculate the extent of compensation and time limit of it, so these will arise lots of problems and hardly in inducing compliance, thus affects the security and predictability of the dispute settlement system. ${ }^{16}$ Moreover, the compensation is not just give to the complaining Member State, but also to all WTO Member States. It is different from the financial compensation. However, a proportion of developing countries are increasingly encouraged to use of monetary compensation,

\footnotetext{
11 P. C. Mavroidis, "Remedies in the WTO legal system-between
} a rock and a hard place," vol. 11, European Journal of International Law, 2000 , p. 778 .

12 If possible, the original one.

13 H. Horn and P. C. Mavroidis, "Remedies in the WTO dispute settlement system and developing country interests," Stockholm University, 1999, pp. 17-18.

14 K. Bagwell, "Remedies in the WTO: an economic persective," No: 0607-09, Department of Economics Discussion Paper Series, 2007, p. 12.

15 C. Carmody, "Remedies and conformity under the WTO agreement," vol. 5, Journal of International Economic Law, 2002, pp. 319 320 .

16 P. Eeckhout, "Remedies and Compliance," in The Oxford Handbook of International Trade Law, D. L. Bethlehem, D. Mcrae, R. Neufeld and I. V. Damme, Eds. New York: Oxford University Press, 2009, p. 453. as part of the proposals submitted to the DSB. Now the major compensation is still trade compensation.

\section{Retaliation Remedy}

Under the compliance-compensation-retaliation remedy system, usually the complaining Member State and defending Member State cannot reach a satisfactory agreement and the defending Member State reluctant to comply with the WTO rules. At the same time, the trade compensation remedy is only used when the dispute Members have a consensus that how to implement it and both of them decide the range of the compensation, on the willingness of the defending Member State. ${ }^{17}$ So the most important remedy under the DSU of the WTO is 'suspend concessions or other obligations', that is retaliation. The form of retaliation usually is the increasing of custom duties in the export interest of defending Member State on chosen products. $^{18}$

Firstly, retaliation maybe a better way to induce compliance with the WTO rules in some circumstances. ${ }^{19}$ As Hudec said, "[The Ecuador Article 22.6 arbitration decision] can be viewed as a formal recognition of the post-WTO tendency to view retaliation as a sanction designed to induce compliance by economic pain, rather than the original view of retaliation as a form of temporary compensation for an imbalance of benefits." ${ }^{20}$ The retaliation has proven to be quite operational which is better than trade compensation in terms of induce compliance. The trade institutions of each government can be the driving force or order to promote compliance. At the same time, if the private parties which interests are affected by retaliation, they will give pressure to their government to comply with WTO rules. As Hudec said above, retaliation is a trade sanction to induce compliance. An advantage for the complaining Member State is that as soon as the DSB authorizes, the complaining Member State can easily impose the sanction on the defending Member State. Trade compensation need a mutual agreement between dispute Members, but in the retaliation, the complaining Member can do itself, which is a self-determination measure. ${ }^{21}$ This is obvious to see and which make the trade sanction more effective in using than other measures. More broadly speaking, retaliation is the ideal way to settle bilateral dispute. In Bananas case, the U.S. government used the retaliation for 28 months and the Government of Ecuador threatened the EC that they would also use the retaliation, so the EC was anxiously to reach the agreements with them to settle the dispute.

\footnotetext{
17 This circumstance rarely happened in fact.

18 For example, increase custom duties up to 100 percent.

19 M. Bronckers and N. V. D. Broek, "Financial compensation in the WTO: improving the remedies of WTO dispute settlement," vol. 8, Journal of International Economic Law, 2005, p. 102.

20 R. E. Hudec, "The adequacy of WTO dispute settlement remedies: a developing country perspective," in Development, Trade and the WTO-A Handbook, B. Hoekman, Bernard, A. Mattoo and P. English, Eds. Washington, DC: The World Bank, 2002, p. 89.

${ }_{21} \quad$ S. Charnovitz, "Rethinking WTO trade sanctions," vol. 95, The American Journal of International Law, 2001, p. 813.
} 
Secondly, the retaliation can promote effective rebalancing which is really a useful tool to rebalance the rights and obligations in the absence of compliance. ${ }^{22}$ In fact, the retaliation is treated as a useful instrument with which the complaining Member State can copy with the trade unfairness it has encountered. This viewpoint focus on that future political and market conditions are both ambiguity for the governments of WTO Members and both of them have the political and economic intentions in it, the trade agreements can be treated as the incomplete contracts between them. Take one circumstance for example, initially the governments can reach an agreement about the selection of tariffs through negotiation. Later on, the political and market conditions change, thus the tariffs may change at the same time. In order to face the possibility, governments try its best to plan a trade agreement that makes them own a positive position when they renegotiate the bargain. Under this aspect, retaliation becomes the useful means to help the governments with the efficiency renegotiation. ${ }^{23}$

Another important purpose for a trade sanction for the complaining Member State is helping itself express its anger, calming down the injured domestic community and then toward a new direction. In Bananas and Hormones cases, the U.S government showed its determination to fight against the noncompliance, which made the U.S. domestic industry companies more comfortable and have the feeling of ownership. Furthermore, the complaining Member State which is in favor of the trade barriers that its imposed on the defending Member State for two reasons. The first one is from the view of trade protection, through the high protection, the domestic political gains would be get of complaining Member State. ${ }^{24}$ Another one is from the aspect of domestic institutions, the high protection from its government makes them more competitive over its foreign competitors, which gives them a good opportunity to improve themselves.

To the defending Member State, the retaliation remedy under the DSU of the WTO also gives it some relief to some extent. According to Charnovitz, there are some due process exist in the WTO. ${ }^{25}$ When the defending Member State faces the sanction, the trade sanction needed to be acquiring the authorization from the DSB, and the defending Member State could seek arbitration to decide the amount imposed on it. $^{26}$ At the same time, when it comes to the compliance with the WTO rules, the defending Member State could gain the political support when it threatened by sanction. As Hudec explains, "Hopefully, the economic pain caused by the

22 S. Charnovitz, "The WTO's problematic 'last resort' against noncompliance," updated version (14 August 2003) of an article written for and published in: Aussenwirtschaft 2002, pp. 9-10.

23 K. Bagwell, "Remedies in the WTO: an economic persective," No: 0607-09, Department of Economics Discussion Paper Series, 2007, p. 9 .

24 H. Horn and P. C. Mavroidis, "Remedies in the WTO dispute settlement system and developing country interests," Stockholm University, 1999, p. 19.

${ }_{25}$ S. Charnovitz, "Rethinking WTO trade sanctions," vol. 95, The American Journal of International Law, 2001, p. 813.

26 Article 22.2, 22.6, 22.7 of the DSU. retaliation will enlist the support of the affected economic interests." 27

\section{THE IMPACTS OF RETALIATION ON DEVELOPED COUNTRIES AND DEVELOPING COUNTRIES-BY COMPARISON}

In fact, by definition, the right to retaliate means the right to impose another illegal measure of WTO on the defending Member State ${ }^{28}$. According to Fernandez, retaliation is treated as an unpopular remedy when copying with noncompliance. ${ }^{29}$ Until now, there are several cases that the DSB gives the authorization to the complaining Member States to take retaliation. However, only a little of them that do the complaining Member States really suspend concessions or other obligations.

The retaliation has influence on both developed countries and developing countries of the WTO Member States. In reality, the more the trade of the Member State affected by the WTO-inconsistent measure, the more harm to the domestic industries and consumers of the Member State. ${ }^{30}$ This is not just a phenomenon for developing countries. In the US-FSC case, the European industry was afraid of losing its suppliers, so it showed strong resistance to the EU' retaliation measure, and because of this, the EU also demonstrated the unwillingness of impose restrictions on the US\$ 4 billion in US imports. In the words of Bronckers and Broek, in the case involved the developed countries, the exporters occupy the decisive position in their countries and their performance makes a big contribution to the development of their country economies. However, when they suffer from the WTO-inconsistent measures, trade retaliation cannot make them feel better. ${ }^{31}$

However, the impacts of trade retaliation on developed countries are pale by comparison with developing countries. To some extent, trade retaliation has little effect on developed countries. On the contrary, use retaliation is not a wise choice for developing countries. The reasons are diversity and most of the developing countries cannot retaliate effectively. More broadly speaking, political and economic power has an essential role in the dispute settlement process. The developed countries have high political and economic power, so when they facing the developing countries, compliance can be easily achieved. By contrast, in the case where a weaker developing country is

27 R. E. Hudec, "Broadening the scope of remedies in WTO dispute settlement," in Improving WTO Dispute Settlement Procedures: Issues and Lessons from the Practice of Other International Courts and Tribunals, F. Weiss, Eds. Cameron May Publishers, 2000, p. 22, available at: http://www.worldtradelaw.net/document.php?id=articles/hudecremedies.pd f.

28 The measure is usually called countermeasure.

29 M. Diego-Fernández, "Compensation and Retaliation: a developing country's perspective," in WTO law and Developing Countries, G. A. Berman and P. C. Mavroidis, Eds. New York: Cambridge University Press, 2007, p. 233.

30 M. Bronckers and N. V. D. Broek, "Financial compensation in the WTO: improving the remedies of WTO dispute settlement," vol. 8, Journal of International Economic Law, 2005, p. 104.

31 Ibid. 
faced with a stronger developed country, the political and economic power between them is inequality and the small economy of the developing country cannot make so much sense on the defending developed country, so it is inevitable that at most time the developed country reluctant to comply with the WTO rules.

Furthermore, retaliation measures are really trade destructive themselves by nature, using them is equal to 'shoot itself in the foot', which is harmful for the Members who using them in terms of domestic industries and consumers, especially for the developing countries. ${ }^{32}$ Their economies are too small and applying retaliation measures is not a real choice. This aspect can be fully demonstrated in the Bananas case. In this case, Ecuador was authorized to impose retaliatory tariff on European import of goods covering US\$ 201.6 million per year. However, in fact, the Ecuador did not find any practicable way to apply the retaliation measures in the fields of GATT and GATS where the EU violated the WTO rules and it found that by using the retaliation measures its own economy would be hurt inevitably. ${ }^{33}$ On the contrary, the United States was authorized to use retaliation measures on EC, which contested the Bananas system successfully. This and later cases, particular the developing countries are the complaints, they all begin to doubt the effectiveness of the retaliation remedy under the DSB of WTO system.

More often than not, the retaliation is time-consuming and costly to the developing complaining Member States. In order to implement a panel decision, the losing Member State is given a reasonable period of time. The benefits of the prevailing Member State can be hindered by this reasonable period of time. ${ }^{34}$ In addition to the appellate process itself, for the purpose of implementation of the panel decision, it is also need the arbitration under Article 21.3(c) of the DSU to make a decision of the time period in order to implement the ruling, and arbitration under Article 22.6 to determine the level of the countermeasures in use. Each of these steps needs a proportion of time, so these can weaken the benefits of the retaliation remedy in reality, especially for the developing countries. For example, when a developed country imposes an antidumping measure on a developing country, and the developing country fight against it successfully, the antidumping measure can still in effect until all of these steps mentioned above have been resolved. It takes a long time, so during this period the extra duties still need to be paid by the exporters of the developing country in order to export their products. When all the steps above finished, it is too late for the exporters, maybe they have lost the market share, maybe they have already go into

\footnotetext{
32 M. Bronckers and N. V. D. Broek, "Financial compensation in the WTO: improving the remedies of WTO dispute settlement," vol. 8 , Journal of International Economic Law, 2005, p. 104.

33 M. Diego-Fernández, "Compensation and Retaliation: a developing country's perspective," in WTO law and Developing Countries, G. A. Berman and P. C. Mavroidis, Eds. New York: Cambridge University Press, 2007, p. 233.

${ }^{34}$ Because of its postponement character.
}

bankruptcy. ${ }^{35}$ However, until now there is no better way to solve this problem. The developing countries have scarce resources and this phenomenon might discourage them in using the dispute settlement proceedings of the WTO. Furthermore, implementing the proceedings under Article 21 and 22 of the DSU also need more resources and the developing countries may not have such resources. The costs of imposing the retaliation measures are too high for the developing countries, and most countries cannot afford them. In sum, before achieving the right to ask for compensation or the authorization to retaliate, the Member State has to wait between three and a half and four years on average. In terms of the case, both the preparation and presentation of it would bring countless legal fees and other spent by the government. The costs almost are $\$ 700$ to $\$ 826$ million according to Fernandez. ${ }^{36}$ At most time the benefits from the retaliation cannot exceed the damage of it, so that is also the reason most developing countries reluctant to seek remedies under the dispute settlement system of WTO. However, the fact is that since 2000, the developing countries have brought more disputes to the WTO than the developed countries. So it is important for the developing countries to be aware of the problems and think up some strategies dealing with this when using the dispute settlement system.

\section{CONCLUSION}

With the economy globalization, more and more trade activities happened among different countries, so with this a great deal of disputes arises. The WTO dispute settlement system plays an essential role in settling the disputes. It is vital to show the significance and the shortage of the remedies under the DSU of WTO, to illustrate the effect of them on different categories of WTO Member States, the developing countries in particular. This essay talks about these briefly. However, in terms of the reform of the remedies under the DSU, the essay does not show much concern, this need to be further research.

\section{REFERENCES}

[1] A. Guzman and B. A. Simmons, "To settle or empanel? an empirical analysis of litigation and settlement at the world trade organization," vol. 31, Journal of Legal Studies, 2002.

[2] C. Carmody, "Remedies and conformity under the WTO agreement," vol. 5, Journal of International Economic Law, 2002.

[3] H. Horn and P. C. Mavroidis, "Remedies in the WTO dispute settlement system and developing country interests," Stockholm University, 1999.

[4] J. H. Jackson, "The WTO dispute settlement understandingmisunderstandings on the nature of legal obligation,", vol. 91, The American Journal of International Law, 1997.

[5] K. Bagwell, "Remedies in the WTO: an economic persective," No: 0607-09, Department of Economics Discussion Paper Series, 2007.

35 M. Diego-Fernández, "Compensation and Retaliation: a developing country's perspective," in WTO law and Developing Countries, G. A. Berman and P. C. Mavroidis, Eds. New York: Cambridge University Press, 2007, p. 240.

$36 \quad$ Ibid., at p. 237. 
[6] M. Bronckers and N. V. D. Broek, "Financial compensation in the WTO: improving the remedies of WTO dispute settlement," vol. 8, Journal of International Economic Law, 2005.

[7] M. Diego-Fernández, "Compensation and Retaliation: a developing country's perspective," in WTO law and Developing Countries, G. A. Berman and P. C. Mavroidis, Eds. New York: Cambridge University Press, 2007.

[8] P. C. Mavroidis, "Remedies in the WTO legal system-between a rock and a hard place," vol. 11, European Journal of International Law, 2000.

[9] P. Eeckhout, "Remedies and Compliance," in The Oxford Handbook of International Trade Law, D. L. Bethlehem, D. Mcrae, R. Neufeld and I. V. Damme, Eds. New York: Oxford University Press, 2009.

[10] P. V. D. Bossche and W. Zdouc, The Law and Policy of the world trade organization--text, cases and materials, 3rd ed., New York: Cambridge University Press, 2013.

[11] R. E. Hudec, "Broadening the scope of remedies in WTO dispute settlement," in Improving WTO Dispute Settlement Procedures: Issues and Lessons from the Practice of Other International Courts and Tribunals, F. Weiss, Eds. Cameron May Publishers, 2000, available http://www.worldtradelaw.net/document.php?id=articles/hudecremed ies.pdf.

[12] R. E. Hudec, "The adequacy of WTO dispute settlement remedies: a developing country perspective," in Development, Trade and the WTO-A Handbook, B. Hoekman, Bernard, A. Mattoo and P. English, Eds. Washington, DC: The World Bank, 2002.

[13] S. Charnovitz, "Rethinking WTO trade sanctions," vol. 95, The American Journal of International Law, 2001.

[14] S. Charnovitz, "The WTO's problematic 'last resort' against noncompliance," updated version (14 August 2003) of an article written for and published in: Aussenwirtschaft 2002.

[15] W. F. Schwartz and A. O. Sykes, "The economic structure of renegotiation and dispute resolution in the WTO/GATT system," John M. Olin Law \& Economics Working Paper No. 143 (2D Series), 2011. 